Jap. J. Ornithol. 45: 167-174, 1996

\title{
Seasonal Change in Nest Site and Nest Success of Bull-headed Shrikes
}

\author{
Masaoki TAKAGI and Shiori ABE \\ Laboratory of Applied Zoology, Faculty of Agriculture, \\ Hokkaido University, Sapporo 060, Japan
}

\begin{abstract}
Seasonal changes in nesting vegetation, nest height, and nest success of the Bull-headed Shrike Lanius bucephalus were studied in Hokkaido, northern Japan from 1992 to 1995. Bull-headed Shrikes nested in dwarf bamboo and vine bushes in early breeding season; however, as the season progressed they moved their nest sites to a variety of deciduous shrubs as the foliage of these nesting plants increased. Nest height gradually increased throughout the breeding season, an observation that was attributed to seasonal changes in the use of nesting vegetation types. Bullheaded Shrikes showed a seasonal change of nest sites with the progress of plant phenology, and the change decreased the probability of predation.
\end{abstract}

Key words: Bull-headed Shrike, Lanius bucephalus, Nest height, Nest success, Seasonal change of Nest sites

Nest predation is considered to be the major cause of nest failure for many species of birds (NILSSON 1984, MARTIN 1992). It has been suggested that various characteristics of nest sites (e.g., concealment, tree species, height, distance from the forest edge, and so on) influence nest success (e.g., GAtes \& Gysel 1978, Martin 1987, Graham 1988, Knopf \& SEDGwick 1992). In temperate zones, the environment for breeding birds changes drastically as nesting trees and herbs foliate. Many authors (e.g., YAmagishi 1970, YARner \& SCOTT 1988, GAwlik \& BildSTEIN 1990, Filliater et al. 1994) have stressed that the relationship between plant phenology and predation risk is an important factor for nest site selection by open-cup nesters. However, there is only one study where the effects of leafing were measured quantitatively in relation to the predation risk (SANTOS \& TELleria 1991). In order to study habitat selection by a bird species in temperate zones, we should pay attention to the temporally changing factors.

In this paper, we describe breeding habitat of Bull-headed Shrikes Lanius bucephalus in Hokkaido, northern Japan. Bull-headed Shrikes are monogamous, single-brooded (although a few are double-brooded), open-cup nesters that replace depredated clutches during breeding season. Females incubate alone, but both sexes feed the young. The diameter of their nests measures about $15 \mathrm{~cm}$. Clutch sizes, which range from 3 to 6 eggs. Eggs are laid between mid-April - early July ( $\mathrm{T}$ AKAGI unpublished data). Because of their protracted breeding season, Bull-headed Shrikes are suitable subjects for studying seasonal change in nest sites. The objectives of this paper are (1) to clarify alliances between temporal changes in nest height, types of nesting vegetation and plant growth (as foliage increases), (2) to investigate relationships among nest height, types of nesting vegetation, and nest 
success.

\section{STUDY SITE AND METHODS}

The study was conducted during April-July, 1992 - 1995 in Oyafuru about $15 \mathrm{~km}$ north of Sapporo $\left(43^{\circ} 13^{\prime} \mathrm{N}, 141^{\circ} 20^{\prime} \mathrm{E}\right)$. The area consisted mainly of pastures and crop lands with wind shelter-belts composed of ash Fraxinus mandshurica, painted maple Acer mono, and Japanese alder Alnus japonica. Manchurian crab Malus baccata, panicle hydranger Hydrangea paniculata, and willows Salix spp. were distributed among fallow fields where dwarf bamboo Sasa senanensi and goldenrod Solidago altissima were dominant plants.

To detect temporal changes in nest sites, the clutch initiation date was determined, the types of nesting vegetation was identified, and the height of each nest above the ground was measured. Nest height is defined as the distance from the outside bottom of the nest cup to the ground.

In order to determine the clutch initiation date and nest success, nest contents were checked at one- to six-day intervals until they either fledged or failed. If the exact clutch-initiation date could not be confirmed, it was estimated by backdating from the hatching date, assuming an incubation period of 15 days (as determined in a study by TAKAGI 1994). For those nests where it was not possible to determine hatching date, we calculated clutch initiation dates by aging the nestlings, using the growth mass of known-age nestlings (TAKAGI 1994) and back calculating. We categorized nests either as successful (nests that fledged at least one young, including those where the nestling fledged even though the nest was parasitized by the Common Cuckoo Cuculus canorus) or depredated. If all eggs or nestlings disappeared between nest visits, we considered the nest to be depredated.

We found 150 nests during the four breeding seasons. We excluded 22 nests from analyses of the relationships between each character of nest sites and nest fate, because 8 fell down before nest heights had been measured, and 14 were deserted during incubation. Therefore, 128 nests were available for the analysis. On the other hand, 136 nests were used in the study of the seasonal change in nesting vegetation, as only 14 nests were excluded. Because of the small sample size in each year (i.e., 1992: 18 nests, 1993: 24 nests, 1994: 52 nests, and 1995: 42 nests), data from four years of the study were pooled for the analysis. To detect the seasonal change in types of nesting vegetation, we divided the breeding season into six periods. However, to secure enough data for the statistical analysis of the relationships among nesting fate, types of nesting vegetation, and nest height, the six periods (two each of earlier, middle, and later periods) were collapsed into three (early, middle, and late) periods.

To determine the seasonal change in the foliation of shrubs and vines, we measured the length of shoots for three nesting deciduous shrub species (Manchurian crab, panicle hydranger, and red-berried elder Sambucus sieboldiana) and vines to the nearest $0.1 \mathrm{~mm}$, once a week from late April to early July 1994. The growth of shoots corresponds to the extent of leaf-out in these plant species. The shrubs and vines were the shrikes' main nesting substrates (TAKAGI 1994). We define the shoot length as the distance from the base of the shoot to the tip. We randomly selected 15 shrub patches from each shrub species and 10 from vines. Eight shoots were selected and measured from four directions (north, south, east, and west) of 
the upper and lower parts of each shrub that divided into two substrates. The timing of foliation did not significantly differ among the four years of our study.

In 1994 and 1995, we estimated the type of nest predators during egg laying, incubation, and nestling phases by the traces of predation.

Statistical analyses were performed using StatView (Abacus Concepts Inc., Berkeley, CA). The statistical tests were two-tailed with a significance level at .05. When we compared height of nests in each type of vegetation, the standard Bonferoni technique was applied at the adjusted significance levels (as suggested in RICE 1990).

\section{RESULTS}

1) Temporal changes in nesting vegetation, nest height, and plant growth

Shrikes selected their nest sites in dwarf bamboos covered by old leaves and dense vine bushes during earlier breeding periods (Fig. 1). They also nested in coniferous shrubs, dwarf plum-yew Cephalotaxus harringtonia and Japanese yew Taxus cuspidata with evergreen leaves. As the season progressed, shrikes nested increasingly in deciduous shrubs (Fig. 1). The main nesting shrubs were Manchurian crab, panicle hydranger, red-berried elder, and willows. In contrast, shrikes' nesting attempts in dwarf bamboo declined over the breeding season. The predominant nest substrate differed among breeding periods (G-test, $G=32.6, d f$ $=4, P<0.0001$ ). As for the phenology of nesting vegetation, shoots of the four plant species grew continually from mid-May to mid-June (Fig. 2). The portion of deciduous shrubs used by shrikes for nesting was proportional to the increase in leafing of the particular plant species, while portion of dwarf bamboo used varied

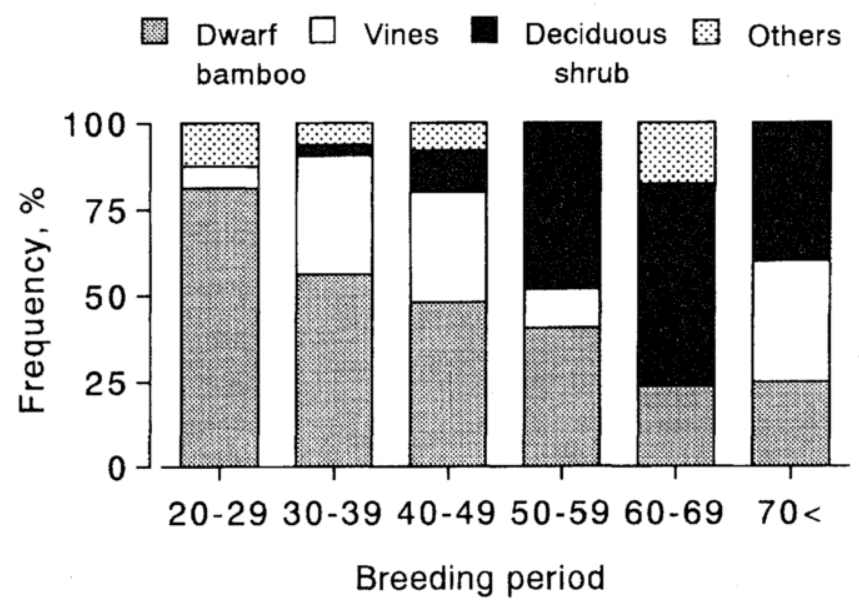

Fig. 1. Seasonal change of types of nesting vegetation. Deciduous shrubs consisted of Manchurian crab Malus baccata, panicle hydranger Hydrangea paniculata, red-berried elder Sambucus sieboldiana, and Willows Salix spp. "Others" are composed by dwarf plum-yew Cephalotaxus harringtonia, Japanese yew Taxus cuspidata, and Japanese larch Larix leptoleps. Data were collected from 1992 to 1995. 


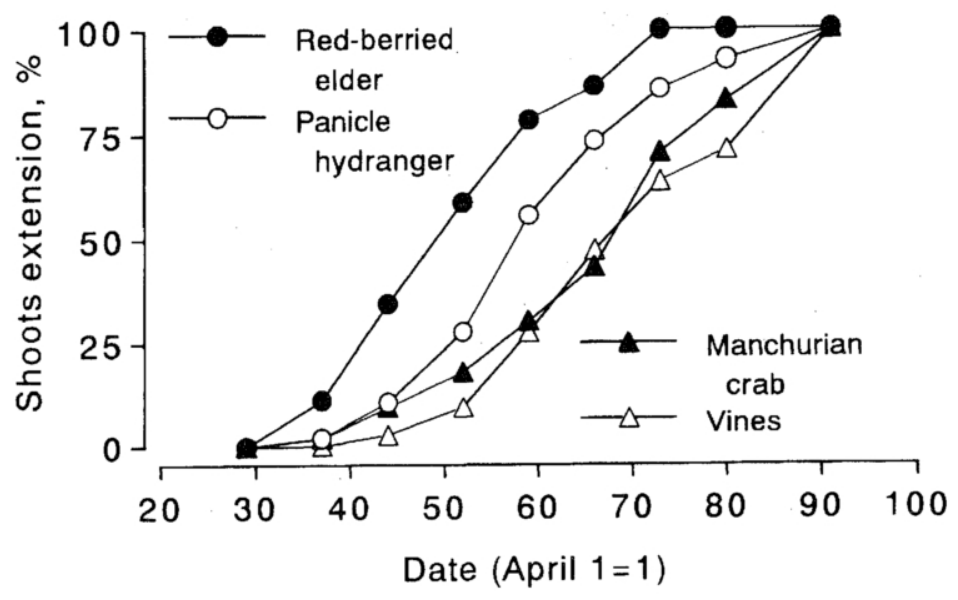

Fig. 2. Growth of shoots in three shrub species (red-berried elder, panicle hydranger, and Manchurian crab) and vines. Yaxis, shoot expansion represents that shoot lengths on each measuring day $\mathrm{x} 100 /$ the length on the last measuring day (\%). The survey was conducted in May-July 1994. Number of shoot of Manchurian crab, Panicle hydrangea, Redberried elder, and vine were $89,100,79$ and 35 , respectively.

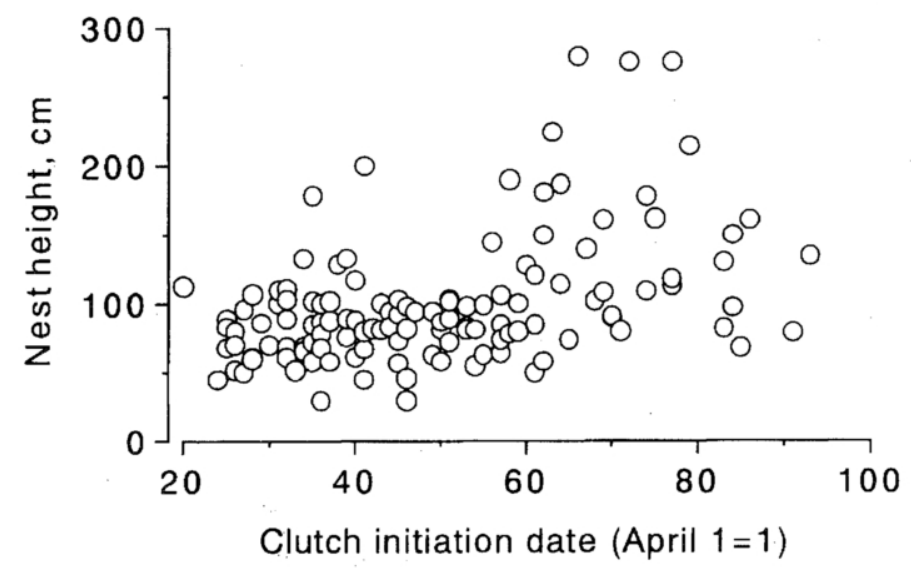

Fig. 3. Seasonal change in nest height. Data were collected from 1992 to 1995.

inversely with the increase of foliage in the deciduous shrubs.

To examine seasonal change in nest height, the relationship between clutch initiation date and nest height was analyzed. Shrikes nested increasingly higher positions as the breeding season progressed (Kendall's rank correlation coefficient, $\tau=0.26$, $z=4.33, P<0.0001)$. The seasonal change in nest height corresponded with the expansion of leaves on the various deciduous shrub species (Figs. 2, 3).

The relationship between the clutch initiation date and the nest height in each 
vegetation was analyzed separately. The height of nests constructed in vines and dwarf bamboo did not changed throughout the season (Vines, $\tau=-0.01, z=-0.08$, NS; Dwarf bamboo, $\tau=0.12, z=1.14, N S$ ). However, shrikes nested in higher positions in deciduous shrubs and others, as the season progressed (Deciduous shrub, $\tau=0.32, z=2.62, P<0.008$; Others, $\tau=0.53, P<0.05$ ). Mean nest height $\pm \mathrm{SD}(\mathrm{n})$ in dwarf bamboo, vines, deciduous shrub, and others was $77.7 \mathrm{~cm} \pm$ 20.4 (59), $107 \mathrm{~cm} \pm 40.2$ (27), $122.8 \mathrm{~cm} \pm 52.7$ (33) and $137.4 \mathrm{~cm} \pm 79.6$ (9), respectively. Nest height in dwarf bamboo were significantly lower than those in three other vegetation types (i.e., dwarf bamboo vs. vines: $U=388.5, z=-3.8, P$ $<0.05$; deciduous shrubs: $U=331.0, z=-5.2, P<0.05$; others: $\mathrm{U}=133.0, z=-2.4$, $\mathrm{P}<0.05)$. There were no differences in nest height between other types of vegetation. It was suggested that the seasonal increase in nest height was caused by the seasonal change in the composition of the vegetation types used in nesting.

2) The relationships among nesting vegetation, nest height, and nest success

In the analyses of nest success in relation to the types of vegetation, early and late periods were combined, as nest success rates in the two periods were similar. Nest success rates were significantly higher in the late period than in the early/middle periods for both deciduous shrub and others (Fisher's exact probability test, deciduous shrub, $P=0.04$; others, $P=0.01$, see Table 1 ). However, there were no significant differences in nest success between early/middle and late periods in dwarf bamboo and vines (Fisher's exact probability test, dwarf bamboo, $P$ $>0.99$; Vines, $P=0.44$, Table 1 ).

The difference in mean height between successful and depredated nests was not Significant in the earlier breeding period. Heights of successful nests in the late period were remarkably higher than those of depredated nests (Table 2), though height of successful nests in the middle period were lower than those of depredated nests.

3) Predators

Potential nest predators in the study area were red foxes Vulpes vulpes, weasels Mustela spp., rats Rattus spp, domestic cats Felis catus, snakes Elaphe quadrivirgata, E. climacophora, Crows Corvus corone, C. macrorhynchos and

Table 1. Nest success, number of successful nest $\mathrm{x} 100 /$ total number of nest (\%), in relation to vegetation type in each period. Data collected during April-Juiy, 1992-1995. Numeralsin parentheses show: number successful nests/number of depredated nest.

\begin{tabular}{crrrrr}
\hline Breeding & \multicolumn{4}{c}{ Nesting vegetation } & \\
\cline { 2 - 5 } period & Dwarf bamboo & \multicolumn{1}{c}{ Vines } & Deciduous Shrub & \multicolumn{1}{c}{ Others } & Total \\
\hline Early & $48.4(15 / 16)$ & $50(6 / 6)$ & $0(0 / 1)$ & $0(0 / 4)$ & $43.8(21 / 27)$ \\
Middle & $52.2(12 / 11)$ & $36.4(4 / 7)$ & $31.3(5 / 11)$ & $0(0 / 2)$ & $40.4(21 / 31)$ \\
Late & $44.4(4 / 5)$ & $28.6(2 / 5)$ & $68.6(11 / 6)$ & $100(3 / 0)$ & $55.6(20 / 16)$ \\
\hline
\end{tabular}


Table 2. Mean nest height $\pm \mathrm{SD}(\mathrm{n})$ in relation to nest fate in each period. Data collected during April-Juiy, 1992-1995.

\begin{tabular}{|c|c|c|c|}
\hline \multirow{2}{*}{$\begin{array}{l}\text { Breeding } \\
\text { period }\end{array}$} & \multicolumn{2}{|c|}{ Nest height } & \multirow{2}{*}{$\begin{array}{c}\text { Mann-Whitney } \\
\text { U-test }\end{array}$} \\
\hline & Successful nests & Depredated nests & \\
\hline Early & $91.9 \pm 26.6(20)$ & $79.1 \pm 27.5(25)$ & $\mathrm{U}=186, \mathrm{z}=-1.5, \mathrm{NS}$ \\
\hline Middle & $70.5 \pm 31.4(20)$ & $98.93 \pm 19.0(28)$ & $\mathrm{U}=107, \mathrm{z}=-3.6, \mathrm{P}<0.001$ \\
\hline Late & $159.1 \pm 29.9(20)$ & $105.9 \pm 68.3(15)$ & $\mathrm{U}=75.5, \mathrm{z}=-2.5, \mathrm{P}<0.01$ \\
\hline
\end{tabular}

Table 3. Classification of depredated nests by traces of predation. Data collected April-Juiy, 1994-1995. Parentheses show percentages.

\begin{tabular}{|c|c|c|c|c|c|}
\hline \multirow[b]{2}{*}{$\begin{array}{c}\text { Breeding } \\
\text { period }\end{array}$} & \multicolumn{2}{|c|}{ Predation by ground mammals } & \multicolumn{2}{|c|}{ Predation by unknown predators } & \multirow[b]{2}{*}{$\begin{array}{c}\text { Total no. } \\
\text { nests }\end{array}$} \\
\hline & $\begin{array}{r}\text { Fell down/ } \\
\text { collapsed }\end{array}$ & $\begin{array}{c}\text { Teeth marks } \\
\text { on eggs* }\end{array}$ & $\begin{array}{c}\text { Without any } \\
\text { traces }\end{array}$ & $\begin{array}{c}\text { Nests material } \\
\text { extracted }\end{array}$ & \\
\hline Early & $10(47.6)$ & $4(19)$ & $6(28.6)$ & $1(4.8)$ & $21(100)$ \\
\hline Middle & $4(21.1)$ & $2(10.5)$ & $12(63.2)$ & $1(5.3)$ & $19(100)$ \\
\hline Late & $5(33.3)$ & $0(0)$ & $9(66.7)$ & $1(6.7)$ & $15(100)$ \\
\hline
\end{tabular}

* The eggs were eaten by rats or weasels.

Northern Goshawks Accipiter gentilis. Apparently, most of the predation in the early period were caused by mammals (Table 3 ). On the other hand, many of the predations were without any trace of damage in the middle and late periods (Table 3 ). In the aggregate of the three periods, 25 nests of 55 depredated nests were those certainly attacked by mammalian predators based on the fact that 19 nests had been knocked down and/or collapsed and the other 6 contained eggs with teeth marks of rats or weasels. With the other 30 nests, nest materials were extracted in 3 nests and all eggs were stolen by unknown predators without any trace of nest disturbance in the remaining 27 .

\section{DISCUSSION}

Loggerhead Shrikes Lanius ludovicianus build their nests at low sites early in the breeding season despite the probably increased risk of possible predation. Their site selection presumably results in protection of their nests from early spring weather (GAWLIK \& BILDSTEIN 1990). Although there was no nest that was damaged by strong wind or heavy rain in our study area, we could not find evidence as to whether or weather influenced nest success.

It has been suggested that the concealment of eggs, young, and adults has a major anti-predator function against avian predators in arboreal breeding species 
(Westmoreland \& Best 1985, Martin \& Roper 1988, Knopf \& Sedgwick 1992, but see Holway 1991, Gtmach et al. 1995). Our Bull-headed Shrikes would also build their nests in sites concealed by leaves or twigs, most likely in order to avoid predation. In earlier breeding season, dwarf bamboo with dense foliage was mainly available for nest sites because deciduous shrub species had not yet leafedout (Fig. 2). However, since dwarf bamboo was not a higher substrate, it did not provide as safe a site for nesting as did the deciduous shrubs later in the season. Thus, nesting in the early period would result in the higher probability of mammalian predation (Table 3 ).

It is suggested that the predation probability of artificial avian nests above ground is lower than that on the ground (YAHNER et al. 1989). However, there is evidence that in some cases the opposite situation has been found (SANTOS \& TElleRia 1991). Furthermore, in a study by RATTI \& REESE (1988) no difference was found in predation probability between ground and arboreal nests. In Loggerhead Shrikes, nest height was affected by the vegetation, and the nest success was influenced by only the type of nesting vegetation (KRIDELBAUGH 1983). These suggest that the difference in predation probability in relation to nest position varying with the type of predators in the area. In the present study $46 \%$ of total nests were depredated by ground mammals. Some of the other depredated nests without any trace of damage could be attributable to snakes. The snake species E. quadrivirgata does not disturb the open-cup nests when it depredates eggs or nestlings (M. Ueta, personal communication, July, 25, 1996). Thus, terrestrial predators as well as avian predators may influence the nest failures of shrikes. Shrikes must build their nests at higher positions to avoid terrestrial predators. Since the nests were constructed at higher positions in the middle and late periods, they would be safe from ground mammals (Table 3).

In the middle period, the height of depredated nests was higher than successful nests, a finding that appeared to be inconsistent with our hypothesis. As leaves of higher layer in deciduous tree species were not fully grown during this period, nests built in deciduous shrubs might be easily detected by avian predators. Hence, shrikes might have been confronted by the dilemma that while they needed to build their nests in higher positions to avoid nest predation by ground predators higher substrate was not available for nesting and, during the earlier season at least, this left them vulnerable to attack from avian predators. With shoots expansion in the shrubs, the increasing availability of nest sites would induce shrikes to change types of nesting vegetation.

As a consequence, Bull-headed Shrikes show a seasonal change in the use of nesting vegetation in relation to the plant phenology, and the shifts of nesting sites would allow shrikes to increase their nest success.

We are indebted to Drs. H. Abe, Y. Watanuki, N. Sodhi, and Miss E. C. Hayashi for their valuable comments and improvement of this manuscript, to Mr. M. Ueta for providing his observational data, and especially Dr. C. K. Curtis for improving the Enghish in the manuscript. We specially thank the Hasegawa family for many kindnesses during our field study. 


\section{LITERATURE CITED}

Filliater, T. S., Breitwisch, R. \& Nealen, P. M., 1994. Predation on northern cardinal nests: does choice of nest site matter? Condor 96: 761-768.

Gates, J. E. \& Gysel, L. W., 1978. Avian nest dispersion and fledging success in field-forest ecotones. Ecology 59: 871-883.

Gawlik, D. E. \& Bildstein, K. L., 1990. Reproductive success and nesting habitat of Loggerhead Shrikes in North-central South Carolina. Wilson Bull. 102: 37-48.

Gtmach, F., Blomqvist, D., Johansson, O. C. \& Bergkvist, J., 1995. Nest site selection: A trade-off between concealment and view of the surroundings?. J. Avian. Biol. 26: 305-312.

Graham, D. S., 1988. House Finch nest-site selection at Guelph, Ontario. Condor 90: $58-60$.

Holway, D. A., 1991. Nest-site selection and the importance of nest concealment in the Black-throated Blue Warbler. Condor 93: 575-581.

Knopf, F. L. \& SeDGwick, J. A., 1992. An experimental study of nest-site selection by Yellow Warblers. Condor 94: 734-742.

Kridelbaugh, A., 1983. Nesting ecology of the Loggerhead Shrike in central Missouri. Wilson Bull. 95: 303-308.

Martin, T. E., 1987. Artificial nest experiments: effects of nest appearance and type of predator. Condor 89: 925-928.

MARTIN, T. E., 1992. Interaction of nest predation and food limitation in reproductive strategies. Power, D. M. (ed.). Current Ornithology Vol. 9. Plenum Press, New York.

MARTin, T. E. \& Roper, J. J., 1988. Nest predation and nest-site selection of a western population of the hermit thrush. Condor 90: 51-57.

NiLsson, S. G., 1984. The evolution of nest-site selection among hole-nesting birds: the importance of nest predation and competition. Ornis Scand. 15: 167-175.

Ratti, J. T. \& Reese, K. P., 1988. Preliminary test of ecological trap hypothesis. J. Wildl. Manage. 52: 484-491.

RICE, W. R., 1989. Analyzing tables of statistical tests. Evolution 43: 223-225.

Santos, T. \& Telleria, J. L., 1991. Effects of leafing and position on nests in a Mediterranean fragmented forest. Wilson Bull. 103: 676-682.

TAKAGI, M., 1994. Breeding ecology and habitat selection of Bull-headed Shrikes (Lanius bucephalus) and comparative ecology with Brown Shrikes (L. cristatus). M. S. thesis. Hokkaido Univ., Sapporo. (in Japanese with English summary)

Westmoreland, D. \& Best, L. B., 1985. The effect of disturbance on Mourning Dove nesting success. Auk 102: 774-780.

YAMAGishi, S., 1970. Observation on the breeding biology of Emberiza cioides. Misc. Rep. Yamashina Inst. for Ornith. 33/34: 103-130. (in Japanese with English summary)

YahneR, R. H., Morkell, T. E. \& Rachal, J. S., 1989. Effects of edge contrast on depredation of artificial avian nests. J. Wildl. Manage. 53: 1135-1138.

YAHNER, R. H. \& SCOTT, D. P., 1988. Effects of forest fragmentation on depredation of artificial nests. J. Wildl. Manage. 52: 158-161.

(Accepted 1 October 1996) 
る (NAKAmura and Ito 1982, NAKAmURA and KitAhara, 1983). 一方, アンドロジェン（雄 性ホルモン）は春の渡りの調節因子である可能性が示唆されている（RANKIN 1991）。さらにふん のアンドロジェンを測定することによって血液中のアンドロジェンレベルを推定することが可能になっ てきている (BISHOP and HALL 1991, YAMAGUCHI and I SHII 1991). そこで上記のように光周期 を変化させてオオジュリンを飼育した場合，ふん中のアンドロジェンレベルが「どのような变化」を するのかを調べた.この時対照として留鳥であるホオジロ Emberiza cioides を用いた.

オオジュリンとホオジロの雄を山梨県甲府市郊外で捕獲した後, 各々を一羽づつかごに入れ, 実験 室で飼育した．飼育条件は温度 $22^{\circ} \mathrm{C}$, 湿度 $50 \%$ でほぼ一定にして, 光周期のみをLD10:14からLD15: 9 まで, 一週間に 30 分づつ明期を長く, 闇期を短く変化させた. そして飼育期間中に両種とも $3 \sim 6$ 個体のふんを定期的に採取し，一定量を蒸留水でホモジェナイズし，このホモジェネートを遠心した 後, 上澄みをジェチルェーテルで抽出し，この抽出物中のアンドロジェンをラジオイムノアッセイに より定量した。

その結果，オオジュリンにおけるふん中のアンドロジェン含量はLD10:14とLD11:13では低いレべ ルであったが, LD12:12で急激に增加した．その後，やや減少したがLD14:10までは比較的高いレべ ルを維持した．一方，ホオジロでは光周期の変化に対してふん中のアンドロジェン含量は有意な変化 を示さなかった。オオジュリンで観察されたように, LD12:12からLD14:10までの高いアンドロジェ ンレベルを示す光周期は, 渡りの衝動がおきる直前から衝動が活発になる時期と一致した．さらに, ふん中のアンドロジェン含量と血液中のアンドロジェン濃度が増加すると考えられる.

ミヤマシトド Zonotrichia leucophrys gambelii を用いた一連の実験から,アンドロジェンは 春の渡りの調節因子の一つであることが示唆されている (RANKIN, 1991). したがって, 本研究の結 果からオオジュリンであ春の渡りにおいてはアンドロジェンは重要な役割を果たしているものと推察 される. 今後, 実際にアンドロジェンが春の渡りの調節因子であるのかどうか, さらに検討する必要 がある.

\section{モズの営巣場所と巣立ち成功の季節変化}

(Seasonal Change in Nest Site and Nest Success of Bull-headed Shrikes. 45: 167-174)

\section{高木 昌興・安部 史織}

北海道大学農学部応用動物学教室

T060 札幌市北区北 9 条西 9 丁目

鳥類の繁殖失敗の最も大きな原因は卵や雉の捕食であり, 多くの鳥類は捕食による繁殖失敗を回避 できるような場所を営巣場所として選択する．営巣場所の様々な特徴，たとえば植物による巣の被覆 の度合い, 樹種, 宩の地上からの高さ, 林縁からの距離などが捕食の受け易さ, 受け難さに関係して いる. しかし, 温带域で繁殖する鳥類にとっての営巣環境は季節の進行と共に樹木や草本か開葉, 伸 長するので大きく変化する．したがって，鳥類の巣場所選択の研究においては，営巣環境の季節変化 と鳥が選択する巣場所の季節変化をともに解明する必要がある. 多くの研究者は植物の季節性が皿型 の巣で繁殖する鳥類の捕食圧に関連して重要であることを強調しているが, 捕食と植物の季節性の関 係を定量的に明らかにした論文はほとんどない. 本研究は, 1) モズ Lanius bucephalus が営巣 した植生の種類および栄の地上からの高さの季節変化と営巣植物の開葉の季節変化の対応関係を明ら 
かにし，2）巣立ち成功を評価関数にして営巣植物，および巣の高さの季節変化の意義を検討した.

調查は1992年から1995年の 4 月から 7 月まで, 北海道石狩郡の農耕牧草地で行なった。 モズが営巣 する植生の利用頻度の季節变化を分析した結果, 繁殖期前期には前年の葉で覆われたクマイザサ Sasa senanensi やッル植物のッルで覆われた場所に営巣し, 矮性の常緑針葉樹 ハイイヌガヤ Cephalotaxus harringtonia, イチイ Taxus cuspidata にあ営巣し, 落葉広葉樹の低木の利用 頻度は低かった（Fig. 1). 繁殖期が進行するにつれてササおよびッル植物の利用頻度はともに低下 したのに対し, 落葉広葉樹の低木であるエゾノコリンゴ Malus baccata, ノリウッギ Hydrangea paniculata, エゾニワトコ Sambucus sieboldiana, ヤナギ類 Salix spp. の利用頻度は上昇し た (Fig. 1). 繁殖期後期ではササの利用頻度がさらに低下し, 落葉低木の利用頻度は上昇した (Fig. 1). これらの落葉低木は繁殖期中期に一気に伸長し, 後期にかけて開葉しきる状態になって おり, モズが営巣する植生の季節変化は, 植物の開葉の進行に対応していた (Figs. 1, 2).

巣の地上からの高さは, 季節の進行とともに高くなった（Fig. 3). それぞれの植物ごとに巣の高 さの季節変化を見たところ, ササとッル植物は季節を通して巣の高さに変化は認められなかったが, 落葉広葉樹低木とその他の場所における巣の地上高は季節の進行とともに高くなった。 ササに造られ た巣の地上高は他の巣に造られたものよりも有意に低かった. 巣の地上高の季節変化も植物の開葉の 進行に対応していた（Figs. 2，3）。繁殖期初期の巣が低い位置に造られたのは, より高い位置に巣 を被覆する葉が開葉していなかったためと考えられる.

営巣植物のタイプごとに巣立ち成功の季節变動を比較した，その結果，ササおよびッル植物では季 節的な差は認められなかったが, 落葉広葉樹低木とその他では後期が前/中期に比較して巣立ち成功 が有意に高かった（Table 1). 捕食を受けなかった巣之捕食を受けた巣の地上からの高さを比較し た結果, 繁殖期前期では差が認められなかったが, 中期では捕食を受けた巣で高くなり, 後期では捕 食を受けなかった巣の地上高が高かった（Table 2). 地上性のほ乳類による捕食率が前期に高かっ たのは, 巣の地上高が低かったためと考えられ, 中, 後期に低くなったのは巣の地上高が高くなった めであろう (Table 3).

他の鳥の研究では, 地上の巣よりも樹上の巣の方が捕食圧が低いことが実験的に明らかにされてい る. 一方, 逆の結果も示されており, 捕食圧は調査域の捕食者の種類によって異なると考えられる. そこで，1995，96年に捕食を受けた55巣の状況から捕食者を推定した，その結果，46\%（ $\mathrm{n}=25 ）$ が 地上性ほ乳類によって捕食されていた。 また, 巣の構造に全く擋乱の痕跡がない捕食が49\%(27), 巣材が引き出された捕食が $5 \%$ （3）認められた。これらの捕食者は特定できなかったが, 擋乱の痕 跡がない捕食にはへビ類よる捕食が含まれると考えられたので, 本調查域では地上捕食者の捕食圧が 高いといえる. モズが地上捕食者による捕食を逃れるためには営巣場所を高くする必要がある一方で, 植物の開葉の季節性に巣場所の利用可能性が制約されていると考えられた.

これらのことから, モズは植物の季節変化にしたがって, 捕食を回避できるように営巣場所を変化 させていることが示唆された. 